\title{
EFFECT OF THE CULTIVAR AREA AND VARIETY ON THE FATTY ACID COMPOSITION AND OVERALL QUALITY INDEX (OQI) OF VIRGIN OLIVE OIL
}

\author{
ATTA, NAHED M. M., AZZA A. A. AHMED AND A. Y. GIRGIS
}

Fats and Oils Res. Department, Food Tech. Res. Institute, ARC, Giza

(Manuscript received 21 December 2009)

\begin{abstract}
The aim of this paper was to study the effect of different cultivar areas located in Egypt, (Wady El-Netron, El-Esmalia and ElArish) and Varieties (Koronaki, Picual and Arbequin) on the quality characteristics ( $\Delta \mathrm{K}$. FFA, PV, $\mathrm{K}_{232}$ and $\mathrm{K}_{270}$ ) oxidative stability, fatty acid composition, overall quality index and total tocopherols of virgin olive oils of these varieties thus in order to have better knowledge about these properties and components in samples obtained at the same time and the same extraction conditions. These parameters were greatly influenced by the variety and cultivar area, whereas the overall quality index (OQI), fatty acid composition, stability and total tocopherols presented observed differences. These results showed that:

Virgin olive oils of these varieties obtained from El-Arish (A) and Wady El Netron (W) areas showed a higher quality compared with the same varieties grown in El-Esmalia (S) area. Also the results appear to confirm the general consensus on the quality of picual virgin olive oil from El-Arish area (A) are generally of high quality compared to arbequin variety when grown in (S) and (A) areas. While koronaki variety obtained from all areas showed intermediate oil quality characteristics. The results showed increased stability and OQI of the studied varieties with increasing oleic acid / linoleic acid ratio.

Keywords: Virgin olive oil, fatty acid, tocopherols, stability, parameters characteristics and overall quality index (OQI).
\end{abstract}

\section{INTRODUCTION}

In the Mediterranean region, healthy, interesting nutritional and sensorial properties of olive oil have been known for long time. Olive oil being the main fat source of the diet due to it's use with out refining which attribute distinguishable characteristics such as: aroma, taste, colour and nutritive properties than other vegetable oils (Gutierrez, et al., 1999).

Virgin Olive oil is well known for its high content of phenolic substances, amount of oleic acid and tocopherols that are thought to have health - promoting properties (Owen, et al., 2000).

Virgin olive oil possesses a characteristic aroma taste and colour that distinguishes it from other vegetable oils. Consumption is currently increasing thanks 
to its excellent organoleptic and nutritive qualities and to growing consumer preference for minimally processed food (Salvador et al., 2003).

The importance of virgin olive oil is related to it's high levels of monounsaturated fatty acids (mainly oleic acid) and to the presence of minor components including aliphatic and tri-terpenic alcohols, sterols, hydrocarbons, volatiles compounds and several antioxidants (Derya et al., 2009).

Zeitoun et al.,(1991) mentioned that oleic acid was present as major fatty acid of olive oil and its percentage ranged from 66.4 to $78.3 \%$ followed by linoleic from 6.1 to 13.3 , palmitic acid from 8.8 to $15.2 \%$, palmitoleic from 0.0 to $1.7 \%$ and stearic acid from 2.4 to 3.4 and other fatty acids (C14:0, C17:1, C18:3, C20:0, C20:1 and C22:1) represented from 0.0 to $1.0 \%$ of the oil fatty acid composition.

Virgin olive oil, obtained from the first cold pressing, also contains a range of antioxidants and flavour constitutes. The beneficial effects of olive oil are due not only to its high unsaturated / saturated fatty acid ratio, but also to its antioxidants such as vitamin $\mathrm{E}$, carotenoide and phenolic compounds. Triacyl glycerol comprise about $98 \%$ of the oil and oleic acid is its main fatty acid (Gimeno et al., 2002).

The contribution of phenolic components to the shelf life of olive oil has been thoroughly investigated for more time and the relationship between the oxidative stability of the oil and their concentration is well established. Although, polyphenols are also responsible for the olive oil taste (Guiterrez et al., 1999).

The tocopherols in virgin olive are important for their nutritional value and for their antioxidant properties, in that they protect the fat components from autooxidation. They constitute the lipophilic antioxidant group and are noted for their effective inhibition of lipid oxidation in all vegetable oils. $\alpha$-tocopherol, the most important antioxidant accounts for about $95 \%$ of the total tocopherols in virgin olive oil (Aguilera et al., 2005).

The minor components (phenolic compounds and $\alpha$ tocopherol) of olive oil is affected by the cultivar, soil, climate, system of irrigation, ripeness degree and processing methods (Morello et al., 2004).

The total phenols and $\alpha$-tocopherals of virgin olive oils of Spanish and Greek cultivars grown in Northern Tunisia under irrigated high density plantation system, showed significant correlations with oxidative stability, furthermore, the majority of the studied analytical parameters were greatly influenced by the cultivar and environment interaction. Also significant differences between the studied oils were detected (Amira et al., 2009). 
The main olive oil producing countries have been particularly active in recent years in studying the chemical composition of olive oil varieties or oil produced in a specific area and how this relates to oil quality (Salvador, et al., 2003).

The overall quality index (OQI) was introduced by the international olive oil council (IOC) in 1990 to express virgin olive oil quality numerically (IOC, 1990). This is a scale from 0 to 10 which considers four quality parameter: the score for sensory evaluation (SE), free acidity (FFA), K270 and peroxide value (PV) according to (Salvador et al., 2003).

The present study gives the influence of the cultivar area and variety on Quality characteristics, fatty acid composition, total tocopherols, stability and overall quality index of virgin olive oils.

\section{MATERIALS AND METHODS}

\section{Materials}

Olive Fruits

Three varieties of olive fruits Arbequin, Picual and Koronaki cultivars were obtained from El-Arish (A), El-Esmalia (S) and Wady El-Netron (W) areas. The samples represented the studied varieties had been taken from different farmers of these areas

\section{Methods}

\section{A- Oil extraction}

The fruits of Picual, Arbequine and Koronaki varieties. were crushed and rapped in cheese cloth then pressed using a laboratory hydroulic press (carver). The extracted oil was dried over anhydrous sodium sulfate, filtered through whatman filter paper No.1 and kept in brown glass bottles at $-5^{\circ} \mathrm{C}$ till analysis.

\section{B- Analytical Methods}

\section{1- Moisture and total lipid of olive fruits}

Moisture and total lipids were determined according to the method of A.O.A.C. (2000).

\section{2- Quality characteristics of olive oils}

Refractive index at $25^{\circ} \mathrm{C}$, free fatty acid (as oleic percent) and peroxide value (as millieqauivalent / $\mathrm{kg}$ oil) were determined according to the methods described by A.O.A.C. (2000).

\section{3- Absorbency in Ultraviolet}

The U.V. absorption of $1 \%$ solution of the oil in cyclohexane in $2 \mathrm{~cm}$ curvet was measured according to FAO/ WHO (1970) at 232 and 270nm. using Shemadzu spectrophotometer (U.V. Vis 120-20). 


\section{4- Overall quality index (OQI)}

The overall quality index(OQI) was introduced by the international olive council (IOC) in 1990 to express virgin olive oil quality numerically. This is a scale from 0 to 10 that considers four quality parameters. The score for sensory evaluation (SE), free acidity (FA), K270 and peroxide value (PV), determined according to the following equation:

OQI=2.55+0.91SE-0.78FA-7.35K270-0.066PV.(Salvador et al., 2003).

\section{5- Fatty acid composition of the oils}

The fatty acid of the analysed oil samples was determined by GC-Capillary column according to the method reported by IOC (2001).

\section{6- The stability of oils}

The oxidative stability of oils was estimated using Rancimat a 679. (Metrohn Herisou (0, Switzerland at ${ }^{\circ} 100$ with an air flow rate of $201 / \mathrm{hr}$ according to the method described by Mendez et al. 1997).

\section{7- Determination of total tocopherols in oils}

The total tocopherols content in oils were determined according to the method of Wong et al., (1988).

\section{8- Organoleptic Evaluation}

The oil samples (15mg each) were presented in covered blue glasses diameter, $70 \mathrm{~mm}$, capacity $(130 \mathrm{ml})$ at $28 \pm 2 \mathrm{C}$. The glass was warmed and after removing the cover the sample was smelled and then tasted by the panelist to judge its flavor. The different attributes of the oils were assessed and their intensities were evaluated to give a mean value of the panelist's score.

The organoleptic assessment of virgin olive oil, were conducted according to the method described by IOC (1996).

\section{RESULTS AND DISCUSSION}

Table 1. Effect of cultivar area and variety on the moisture and oil contents of olive fruits on the dry matter (\%).

\begin{tabular}{|l|c|c|c|c|c|c|c|c|c|}
\hline \multirow{2}{*}{$\begin{array}{l}\text { Chemical } \\
\text { composition }\end{array}$} & \multicolumn{3}{|c|}{ Koronaki } & \multicolumn{3}{c|}{ Picual } & \multicolumn{3}{c|}{ Arbequin } \\
\cline { 2 - 11 } & $(\mathrm{W})$ & $(\mathrm{S})$ & $(\mathrm{A})$ & $(\mathrm{W})$ & $(\mathrm{S})$ & $(\mathrm{A})$ & $(\mathrm{W})$ & $(\mathrm{S})$ & $(\mathrm{A})$ \\
\hline Moisture content & 52.38 & 54.50 & 52.64 & 58.31 & 59.66 & 58.43 & 52.92 & 52.09 & 51.90 \\
\hline Oil content & 39.00 & 38.00 & 38.26 & 38.54 & 36.76 & 37.50 & 44.48 & 44.00 & 44.25 \\
\hline
\end{tabular}

Whereas:

(W): Wady El Netron area

(S): El- Esmalia area

(A): El-Arish area 


\section{Oil and moisture contents of olive fruits}

From the tabulated data in table (1) it could be noticed that, no clear differences as a result effect of cultivar area $((\mathrm{W}),(\mathrm{S})$, and $(\mathrm{A})$ areas) on the oil and moisture contents of koronaki, picaul and Arbequin varieties. On the contrary, the oil and moisture contents of olive fruits depend on the variety of olive fruits whereas the oil content of Arbequin variety recorded a higher percentage compared with Koronaki and picual varieties in all cultivar areas.

Table 2. Effect of the cultivar area on the fatty acid composition of virgin olive oils of Koronaki variety $(\%)$.

\begin{tabular}{|l|c|c|c|}
\hline Areas cultivar & $(\mathrm{W})$ & $(\mathrm{S})$ & $(\mathrm{A})$ \\
\hline F.A. Composition :- & & & 15.88 \\
\hline C16:0 & 15.29 & 16.39 & 1.09 \\
\hline C16:1 & 1.55 & 1.95 & 0.05 \\
\hline C17:0 & - & - & 0.07 \\
\hline C17:1 & - & - & 2.62 \\
\hline C18:0 & 1.97 & 1.57 & 68.68 \\
\hline C18:1 & 71.38 & 67.18 & 9.84 \\
\hline C18:2 & 9.03 & 12.03 & 0.95 \\
\hline C18:3 & 0.78 & 0.88 & 0.48 \\
\hline C20:0 & - & - & 0.34 \\
\hline C20:1 & - & - & 19.03 \\
\hline Total sat. F.A. & 17.26 & 17.96 & 80.97 \\
\hline Total unsat. F.A. & 82.74 & 82.04 & \\
\hline
\end{tabular}

Table 3. Effect of the cultivar area on the fatty acid composition of virgin olive oils of Picual variety (\%).

\begin{tabular}{|l|c|c|c|}
\hline Areas cultivar & $(\mathrm{W})$ & $(\mathrm{S})$ & $(\mathrm{A})$ \\
\hline F.A. Composition :- & & & \\
\hline C16:0 & 15.24 & 16.39 & 14.10 \\
\hline C16:1 & 2.03 & 2.72 & 1.83 \\
\hline C17:0 & - & - & 0.05 \\
\hline C17:1 & - & - & 0.09 \\
\hline C18:0 & 3.53 & 2.27 & 2.65 \\
\hline C18:1 & 70.25 & 66.52 & 73.89 \\
\hline C18:2 & 7.92 & 11.29 & 5.92 \\
\hline C18:3 & 1.03 & 1.12 & 0.82 \\
\hline C20:0 & - & - & 0.42 \\
\hline C20:1 & - & - & 0.23 \\
\hline Total sat. F.A. & 18.77 & 18.35 & 17.22 \\
\hline Total unsat. F.A. & 81.23 & 81.65 & 82.78 \\
\hline
\end{tabular}


Table 4. Effect of the cultivar area on the fatty acids composition of virgin olive oils of Arbequin variety (\%).

\begin{tabular}{|l|c|c|c|}
\hline Areas cultivar & $(\mathrm{W})$ & $(\mathrm{S})$ & (A) \\
\hline F.A. Composition :- & & & 18.84 \\
\hline C16:0 & 20.14 & 20.90 & 1.96 \\
\hline C16:1 $17: 0$ & 2.94 & 3.40 & 0.05 \\
\hline C17:1 & - & - & 0.07 \\
\hline C18:0 & - & - & 2.20 \\
\hline C18:1 & 1.81 & 1.37 & 56.42 \\
\hline C18:2 & 57.05 & 52.84 & 18.64 \\
\hline C18:3 & 17.01 & 20.65 & 1.01 \\
\hline C20:0 & 1.05 & 0.84 & 0.96 \\
\hline C20:1 & - & - & 0.85 \\
\hline Total sat. F.A. & - & - & 22.05 \\
\hline Total unsat. F.A. & 21.95 & 22.27 & 77.95 \\
\hline
\end{tabular}

Tables (2, 3 and 4) show the fatty acid composition of virgin olive oils of koronaki, picual and arbequim varieties obtained from different production areas located in Egypt, Wady El-Netron (W), El-Esmalia (S) and El-Arish (A). As shown in these tables, many fatty acids were detected in the virgin olive oils of all studied varieties, palmatic, oleic and linoleic were considered as a major fatty acid while stearic, limolenic and areachidic acids were present in small amounts, Palmitic acid, the major saturated fatty acid showed a wide variability depending on the cultivar area and the variety. The maximum values of $20.9,20.14$ and $18.84 \%$ were observed in Arbequin virgin olive oils cultivated in (S), (W), and (A) areas respectively, followed by 16.39, 15.88 and 15.15, observed in Koronaki varieties grown in (S), (A) and (W) areas respectively, and then $16.39,15.24$ and $14.1 \%$ showed in virgin olive of picual variety cultivated in (S), (W) and (A) areas respectively. Oleic acid, the major unsaturated fatty acid showed also wide variability depending on the cultivar area and variety, it is especially high in virgin olive oil of picual variety.(73.83, 70.25 and $66.52 \%$ ) obtained from (A), (W) and (S) areas respectively also in Koronaki oils were $71.38,68.68$ and $67.18 \%$ cultivated in (W), (A) and (S) areas respectively, but it was lowest in arbequin oils grown in (A), (W) and (S) areas (56.42, 57.05 and 52.84\%, respectively).

Concerning linoleic acid, relatively low percentages were observed in the analysis of samples with highest values observed in Arbequin variety. grown in (S), (A) and $(\mathrm{W})$ areas $(20.65,18.64$ and $17.01 \%$, respectively). On the contrary, the lowest one found in picual var. cultivated in (A), (W) and (S) areas (5.92, 7.92 and $11.29 \%$ respectively). While it showed intermediate values in Koronaki variety. when grown in (A), (S) and (W) areas (9.84, 12.03 and $9.03 \%$ respectively). On the other hand, the level of linolenic acid showed minimum values of 0.78 and $0.82 \%$ in Koronaki and Picual cultivated in (W) and (A) areas respectively, but it was more than the level 
( $\leq 1 \%$ ) as in IOC trade standard(2006) in Picual variety cultivated in W and S areas (1.03 and $1.12 \%$ respectively).It also more in Arbequin cultivated in $\mathrm{W}$ and $\mathrm{A}$ areas (1.05 and $1.01 \%$ respectively ).Levels of these fatty acids in the various tested oils were close to the results of Zeitoun (1991). Variation in fatty acid composition observed in virgin olive oil samples (Tables 2, 3 and 4) are probably related to both genetic factors and the environmental conditions during the development and maturity of the fruits (Amira 2009).

Table 5. Effect of the cultivar area and variety on the overall quality index and quality characteristics of virgin alive oils.

\begin{tabular}{|c|c|c|c|c|c|c|c|c|c|}
\hline \multirow{2}{*}{$\begin{array}{l}\text { Quality } \\
\text { Characteristics }\end{array}$} & \multicolumn{3}{|c|}{ Koronaki } & \multicolumn{3}{|c|}{ Picual } & \multicolumn{3}{|c|}{ Arbequin } \\
\hline & W & $\mathrm{S}$ & $\mathrm{A}$ & W & $\mathrm{S}$ & $\mathrm{A}$ & W & $\mathrm{S}$ & $\mathrm{A}$ \\
\hline OQI & 6.73 & 6.53 & 6.84 & 7.10 & 6.92 & 8.18 & 4.82 & 3.77 & 4.40 \\
\hline $\begin{array}{l}\text { Peroxide value } \\
\text { (meq/kg oil) }\end{array}$ & 2.85 & 3.42 & 2.90 & 2.92 & 4.72 & 2.22 & 4.73 & 3.59 & 3.05 \\
\hline $\begin{array}{l}\text { Free fatty acid (\%) } \\
\text { as Oleic }\end{array}$ & 0.15 & 0.10 & 0.65 & 0.52 & 0.30 & 0.40 & 0.49 & 0.31 & 0.81 \\
\hline $\mathrm{K}_{270} \mathrm{~nm}$ & 0.132 & 0.098 & 0.126 & 0.166 & 0.073 & 0.100 & 0.153 & 0.40 & 0.119 \\
\hline $\mathrm{K}_{232} \mathrm{~nm}$ & 1.56 & 1.26 & 2.42 & 1.35 & 1.45 & 1.68 & 2.35 & 1.72 & 2.38 \\
\hline $\begin{array}{l}\text { Sensory evaluation } \\
\text { (SE) }\end{array}$ & 6.0 & 5.5 & 6.5 & 7.0 & 6.0 & 7.5 & 4.5 & 3.0 & 4.0 \\
\hline$\Delta \mathrm{K}$ & -0.0025 & -0.002 & -0.015 & -0.001 & -0.003 & -0.018 & -0.0004 & -0.001 & -0.026 \\
\hline Total tocopherols & 277.3 & 254.5 & 134.05 & 206.04 & 134 & 119.97 & 251.6 & 196.07 & 146.40 \\
\hline
\end{tabular}

Data in Table (5) show the overall quality index (OQI) and quality characteristics of virgin olive oils of Koronaki, picual and Arbequin varieties obtained from (W), (S) and $(A)$ area $S$. As shown in this, table, Picual variety when grown in (A) area produced the highest value of OQI of oil (8.18) reflecting the measured lowest values for acidity, peroxide, and K270 and highest value for sensory evaluation (SE). On the other hand, virgin olive oils of Arbequin variety obtained from (W), (S) and (A) areas produced lower values of OQI $(4.82,3.77$ and 4.40 respectively), reflecting mainly high values of acidity, peroxides, and $\mathrm{K}_{270}$ and low in SE. Moreover, Koronaki showed intermediate values in OQI of virgin olive oil obtained from (W), (S) and (A) areas $(6.73,6.53$ and 6.84 respectively, also picual variety when grown in $(W)$ and $(S)$ areas produced intermediate values in OQI (7.10 and 6.92 respectively). The observed difference in chemical properties and quality of virgin olive oils are mainly due to agronomical and climatologic variables (Salvador et al., 2003). 
Concerning total tocopherols of virgin olive oils (VOO). Koronaki variety produced similar values of total tocopherols in Wady El-Netron area (277.31 ppm) as well as Koronaki variety cultivated in (S) area (254.5 ppm). Picual variety. cultivated in the same previous areas produced a higher values of total tocopherols (206.04 ppm) as a compared with those grown in (S) and $(A)$ areas (134 and $119.97 \mathrm{ppm}$ respectively).

Arbequin variety. showed higher values of total tocopherols when grown in (W) area (251.63 ppm) as compared to those cultivated in (A) area (146.48 ppm), but when cultivated in (S) area showed intermediate values of total tocopherols (196.07 ppm). 
Fig 1. Relation of C18:1/C18:2 ratio with the stability and Overall Quality Index (OQI) of virgin olive oil

Table 6. Relation of oleic acid / linoleic acid ratio with the stability and overall quality index of virgin olive oil.

\begin{tabular}{|l|c|c|c|c|c|c|c|c|c|}
\hline \multirow{2}{*}{$\begin{array}{l}\text { Varieties } \\
\text { Areas }\end{array}$} & \multicolumn{3}{|c|}{ Koronaki } & \multicolumn{3}{c|}{ Picual } & \multicolumn{3}{c|}{ Arbequin } \\
\cline { 2 - 10 } & $\mathrm{W}$ & $\mathrm{S}$ & $\mathrm{A}$ & $\mathrm{W}$ & $\mathrm{S}$ & $\mathrm{A}$ & $\mathrm{W}$ & $\mathrm{S}$ & $\mathrm{A}$ \\
\hline $\begin{array}{l}\text { C18:1/ C18:2 } \\
\text { ratio }\end{array}$ & 7.90 & 5.58 & 6.98 & 8.87 & 5.89 & 12.48 & 3.35 & 2.55 & 3.02 \\
\hline Stability & 36.5 & 28.50 & 30.56 & 37.75 & 29.00 & 38.94 & 28.25 & 17.75 & 19.39 \\
\hline $\begin{array}{l}\text { Overall quality } \\
\text { index (OQI) }\end{array}$ & 6.73 & 6.53 & 6.84 & 7.10 & 6.92 & 8.18 & 4.82 & 3.77 & 4.40 \\
\hline
\end{tabular}

The oxidative stability of virgin olive oils obtained from the studied varieties analyzed with Rancimat equipment (Table 6) shows a higher difference related to cultivar area and variety. Virgin olive oils of picual variaty cultivated in A and W ares recorded the highest stability (38.94 and 37.75 hr. respectively) followed by Koronaki variety VOO cultivated in W and A areas ( 36.5 and $30.56 \mathrm{hr}$. respectively) the lowest stability was found in Arbenquin variety VOO . From these results it could be noticed that, virgin olive oils (VOO) of Koronaki and Picual varieties. cultivated in (W) and (A) areas were more stable than virgin olive oil of Arbequin variety. especially cultivated in (S) area , this related to the VOO of Koronaki and picual varieties. contain a higher amount of monounsaturated fatty acid (C18:1) than VOO of Arbequin variety. These results are in agreement with the results obtained by Amira et al., (2009).

As shown in the same table and fig.(1) the oleic acid / linoleic acid ratio were evaluated in the virgin olive oil of the studied varieties. The C18:1/ C18:2 ratio varies between 2.55 to 12.48 according to varieties and cultivar areas. This ratio can be useful to characterize olive cultivars and the have a marked relationship with stability (Amira et al., 2009). Where as, the stability and overall quality index of the virgin olive oil of the studied varieties were increased by increasing the $\mathrm{C} 18: 1 / \mathrm{C} 18: 2$ ratio.

\section{REFERENCES}

1. A. O. A. C. 2000. Official methods of analysis of the Association of official Agricultural Chemists. $15^{\text {th }}$ ed. Published By A. O. A. C.

2. Aguilera, M. P., G. Beltran, D. Ortega, A. Femandez, A. Jimenez and M. Uceda. 2005. Characterisation of virgin olive oil of Italian olive cultivars: Frantoio and Leccino, grown in Andalousia. Food chem., 89, 387-391.

3. Amira Allalout, K., M. Dhouha, T. Kawther, O. Ameni, D. Imen, Z. Douja, Mokhtar. 2009. "Characterization of virgin olive oil from super intensive Spanish and Greek varieties grown in northern Tunisia", Scientia Horticulturae 120, 77-83. 
4. Derya, O., T. Figen, O. Bonu and H. Figen. 2009. Distribution of simple phenols, phenolic acids and flavonoids in Turkish Monovarietal extra virgin olive oils for two harvest years., Food Chem. 113, 401-410.

5. FAO/WHO. 1970. recommended international standard for olive oil, virgin and refined and refined olive residue oil. Codex Almentarius Commission CAC/RS 331970, Food and Agriculture Organization World Heath Organization, Rome, Italy.

6. Gimeno, E., A.I.C. Castellote, R.M., Lamuela-Raventos, M.C.De La Torve and M.C. Lopez-Sabator. 2002. The effects of harvest and extraction methods on the antioxidant content (phenolics, $\alpha$-tocopherols, and $\beta$-carotene) in virgin olive oil. Food Chemistry(78):207-211.

7. Gutierrez, F., T. Arnaud and A. M. Albi. 1999. Influence of ecological cultivation on virgin olive oil quality. J. Am. Oil Chem. Soc. 76 (5), 617-621.

8. IOC. 2001. Method of analysis of the international olive council preparation of the fatty acid methyl esters from olive oil and olive-pomace oil COI/T. 20/DOC. No. 24.

9. IOC, International olive council. 1996. organoleptic Assessment of Virgin Olive oil 20 November, French.

10. IOC, International olive council. 2006. Trade standard Applying to olive oils and olive . Pomace oils COI/T .15/NC no.3/Rev.2,.24 Novembr

11. Mendez, E., J. Sanhveza, II, Speisky and A. Valenzvela, 1997. Comparison oxidative stasbility of fish oil, JAOCS, 74 (3) 331-332.

12. Morello, J. R., M. J. Motilva, M. J. Tovar and M. P. Romero. 2004. Changes in commercial virgin olive oil (CV. Arbequina) during storage with special emphasis on the phenolic fraction, food chem.. 85, 357-364.

13. Owen, R. W., A. Giacosa, W. E. Hull, B. Haubner, B. Spiegelhalder and H. Bartsch. 2000. Identification of lignans as major components in the phenolic fraction of olive oil. Clin, chem. 46, 976-988.

14. Salvador, M. D., F. Aranda, S. Gomez-Alonso and G. Freqapane. 2003. Influence of extraction system, production year area on cornicabra virgin olive oil: a study of five crop seasons", food chemistry 80, 359-366.

15. Wong, L. M., J. E. Timms, E. Rand and ME. Goh. 1988. Colorimetric determination of total tocopherols in palm oil, JAOCS, 65(2) 318-321.

16. Zeitoun, M. A., Neff. Selke and W. E. Mourits. 1991. Analysis of vegetable triglyceride molecular species by reserved phase high performance liquid chromatography. J. Liquid Chromatography 14(4): 2685-2698. 
تأثير منطقة الزراعة و الصنف على تركيب الأحماض الاهنية ومعامل الجودة لزيت الزيتون البكر

ناهد محمد محروس عطا عزة عبد الله أحمد احمدعادل يوسف جرجس

$$
\text { قسم بحوث الزيوت والدهون - معهل بحوث تكنولوجيل الؤذية - مركز البحوث الزراعية - جيزة }
$$

يهدف هذا البحث إلى دراسة تأثير مناطق الزراعة المختلفة في مصر (و ادي النطرون -



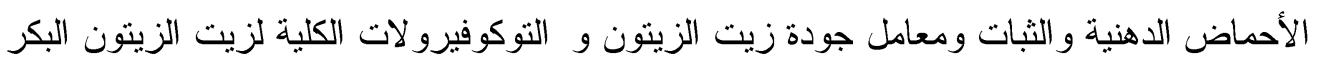

لهذه الأصناف. وذللك لكي نعرف أحسن الخو اص لهذه الأصناف المتحصل عليها من نفس منطقة زئة

$$
\text { الزر اعة ونفس موسم الحصاد ونفس ظروف الاستخلاص. لون. }
$$

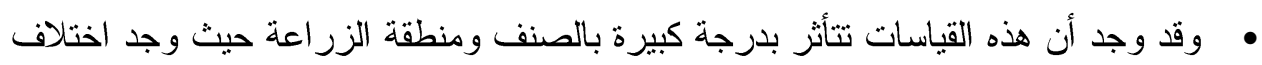

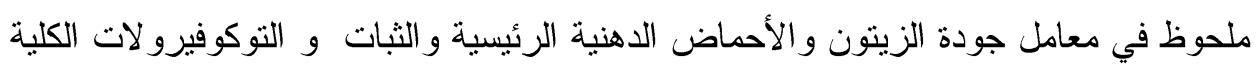

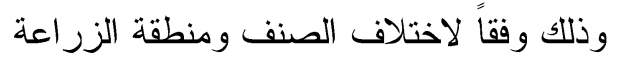

• وقد تنين من النتائج أن خو اص زيت الزينون البكر لهذه الأصناف موضع الدر اسة و المتحصل

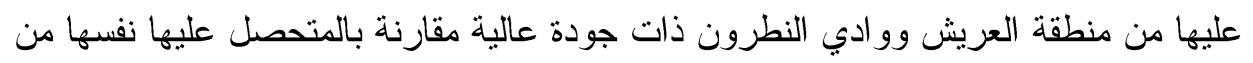


صنف بيكو ال العريش تكون عالية الجودة مقارنة بالصنف أرب كوين من نفس المناطق


عليه من كل المناطق تعتبر وسط بين خو اص الصنف بيكو ال وارب كوين.


النسبة حمض الاوليك / حمض اللينوليك من فئك 